\title{
Twenty Years after Reunification: Comparing Young Consumer Decision- Making Processes for Electronic Products in the Former East and West Germany
}

\author{
Author: Eunyoung (Christine) Sung, Patricia \\ Huddleston, and Sebastian Uhrich
}

This is an Accepted Manuscript of an article published in International Review of Retail, Distribution and Consumer Research on [date of publication], available online: http:// www.tandfonline.com/10.1080/09593969.2011.578800.

Sung, Eunyoung (Christine), Patricia Huddleston, and Sebastian Uhrich. "Twenty Years after Reunification: Comparing Young Consumer Decision-Making Processes for Electronic Products in the Former East and West Germany." The International Review of Retail, Distribution and Consumer Research 21, no. 3 (July 2011): 251-265. doi: 10.1080/09593969.2011.578800.

Made available through Montana State University's $\underline{\text { ScholarWorks }}$ scholarworks.montana.edu 


\title{
Twenty years after reunification: comparing young consumer decision-making processes for electronic products in the former East and West Germany
}

\author{
Eunyoung (Christine) Sung ${ }^{\mathrm{a} *}$, Patricia Huddleston ${ }^{\mathrm{a}}$ and Sebastian Uhrich $^{\mathrm{b}}$ \\ ${ }^{a}$ Department of Advertising, Public Relations, and Retailing, Michigan State University, East \\ Lansing, Michigan, USA; ${ }^{b}$ Department of Marketing and Services Research, University of \\ Rostock, Rostock, Germany
}

(Received 13 July 2010; final version received 7 January 2011)

\begin{abstract}
This article measures and compares influences on purchasing decisions for electronic products among consumers from the former East and West German states. The study is framed using Cohort Theory. To investigate whether changes in the economic system influences consumer behavior, two consumer groups are included: Germans in the former East Germany and former West Germany. The study found that the former West Germans are more likely to be influenced by the opinions of others than East Germans. Brand loyalty is influential for both of the two German groups. In addition, the two German groups had more similar attitudes toward advertising compared to their parents' cohort groups of 20 years ago. The study also found that Inglehart's Cohort Theory applies to the case of German reunification.
\end{abstract}

Keywords: cohort theory; consumer behavior; information source; advertising attitude; brand loyalty

\section{Introduction}

After World War II, many European countries, such as the former East Germany, Poland, Czechoslovakia, Romania, and so on, have transitioned from planned economies to market economies. Among the many cases of these economies is the former East Germany. Following World War II, Germany was divided into two nations - East and West Germany. While the West immediately became a market economy, East Germany was under the control of the United Soviet Socialist Republic (USSR) and therefore was a planned economy. This makes reunified Germany an exceptional case for comparing consumer behavior in a market economy to a transitional economy. Since global marketers enter market economies as well as transitional economies, their marketing strategies for consumers in these two types of economies need to be developed based on understanding consumers' similar and dissimilar behaviors.

The year 2010 is the twentieth anniversary celebrating the reunification of Germany. The governments of West Germany and East Germany were officially 
united in 1990. Although Germany has been reunited in government, we need to examine German consumer behavior for evidence of reunification. After the reunification, young consumers (in their 20s) might have been through similar processes of socioeconomic transition to their parents in the Eastern region of Germany. While most parents of the Soviet era spent their youths in a planned economy, their children have spent their youths in transition from a planned economy to a market economy. They have become adults in this market economy. They have been witnesses to family experiences shaped by this transitional economy changing from a planned to a market economy. During this time they developed their own consumer behavior in this transitional environment.

According to Cohort Theory, significant national events can transform a country's economy, change a society's value structure, and create new generational cohorts (Inglehart 1976, 2000). In this current study, the 1989 fall of the Berlin Wall is treated as a significant national event. Change from a planned economy to a market economy influences both the general economy and the individual values within society (Fam et al. 2008). National events, economic growth, and media effects may affect influences on consumer decision-making processes, such as shifting the information sources to which consumers are exposed, changing their attitudes toward advertising, and transforming their brand loyalty. Market influence on the members of different generations is created by the socioeconomic resources available during their youth; this influence leads to the formation of societal values and attitudes (Fam et al. 2008). The availability of financial resources could moderate the influences from societal change and reduce its impact (Noack et al. 2001). Politics (e.g. governmental change) and availability of finance resources are the most influential elements in family members' perceptions of a society (Noack et al. 2001). For the current study, reunification was a governmental change that led to the change from a planned to a market economy, both of which have heavily influenced the German youth who were raised during that time of upheaval.

During a specific historical time period - in this case, the fall of the Berlin Wall and the subsequent transition to a market economy - generational cohorts act out the values of the society (Egri and Ralston 2004). As the members of a generation age and move into positions of greater authority, their values become the dominant values in the culture (Inglehart 1976).

Johnson and Johnson (1993) examined two groups of German adults and analyzed their consumer behaviors during a 10-week period less than a year after the fall of the Berlin Wall when formerly East German consumers still exhibited consumer behavior as prior to the fall. They found that consumers in East and West Germany had different attitudes toward the use of information sources, advertising approaches, and product price quality. The former West Germans felt more negatively about advertising than the former East Germans. In addition, the opinions of friends and families in the former East Germany were more depended upon than in the former West Germany.

The former East German group in the current study consists of subjects approximately 20-26 years old. Our sample was born between 1983 and 1989 and, although they lived in the pretransition environment, they had very limited consumer experiences in the planned economy. Children who were exposed to a planned economy for only 1 to 6 years and who shopped in a market environment for most of their lives might have had enough time to develop a common German consumer behavior during their lifetime. After the transition, these children were exposed to 
the same media and socioeconomic system influences as the former West German children.

Savitt (1989) emphasized that understanding the past is important when investigating present and future consumer behavior. The same goes for the current study. We look back 20 years at the consumer behavior of adult Germans - the cohort of the current study's subjects' parents - using a previous study (e.g. Johnson and Johnson 1993) as a benchmark. Then, we investigate the consumer behavior of their children's cohort - now in their 20s - who grew up in the transitional economy (East) and market economy (West) during the 20 years following reunification. This process helps retailers understand young German consumer behavior in reunified Germany by analyzing and comparing the past and present, as well as projecting the future behavior of young German consumers as one united group. These young German consumers - now in their 20 s - will become the primary German consumers in the near future. Therefore, we attempt to investigate whether the consumer behavior of young adults in former East and West Germany has converged. This generation will be the major consumer group in the near future; marketers thus need to understand whether they can treat them as one German consumer group or whether differences still exist that must be taken into account.

Global marketers may find both similarities and differences in young adult consumer behavior in market and transitional economies. Thus, the current study is important in several aspects: (1) The case of German consumer behavior is interesting to investigate because the country has simultaneously had a market economy in the Western region of Germany and a transitional economy in the Eastern region. We use the young East German group as the transitional economy group and the young West German group as the market economy group to draw comparisons to explain whether the period of exposure to market economy (East vs. West) is influential on consumer behavior; (2) Global retailers and manufacturers who are interested in transitional emerging (growing) markets should seek to understand the young generation who are growing into adulthood, because this young generation (in their 20s) will become the primary consumers in the future; (3) Twenty years after reunification, there is no empirical work about the purchasing behavior of the East German children, now adults, who grew up during the economic transition and whether this behavior is now different from or similar to former West Germans. The current study fills this knowledge gap by reporting on a survey of young German consumers from the former East and West Germany and examining the influences on their consumer behavior after 20 years in the unified environment. An investigation of this new 'market generation' is important, because this is the original group that experienced a market economy as children. This study seeks, in part, to determine whether there is a unified young adult consumer group or whether residual differences still exist in Germany.

Therefore, the main purpose of the study is to compare young consumer behavior (e.g. information seeking behavior, brand loyalty, and advertising attitude) between the transitional economy in the Eastern region of Germany and the market economy in the Western region of Germany using an intranational study. This comparison will be of interest to firms wishing to target the German market. The results of this intranational comparison study will inform global retailers and manufacturers' decisions related to standardization, adaptation or mixed strategies targeting young consumers in market and transitional emerging economies across the European 
Union. We hope to thereby pinpoint intranational similarities or differences among German consumers.

\section{Literature review and hypotheses}

\section{Theoretical background: generational cohort theory}

Generational cohort theory explains the change of a society, its value structure, and the emergence of new generational cohorts as an outcome of significant national events (Inglehart 1976). Countries with the largest economic growth tend to have the largest differences in values, attitudes, and lifestyles across cohorts (Abramson and Inglehart 1995). A social change in and of itself does not necessarily lead to a quick adjustment in personal values (McKenzie and Merrilees 2008). Thus, moving from a communist to a democratic society does not itself lead to an adoption of democratic culture traits, but rather economic growth facilitates the change of social and cultural traits (Inglehart 2000).

We use cohort theory to examine consumer behaviors among former East German and West German consumers. Specifically, we address (1) choice of information source (consumer information source preference for information, which could significantly affect purchase decision); (2) brand loyalty (to reduce risk, consumers may consistently purchase a brand with which they have had good experiences); and (3) consumer attitude toward advertising. The study model is presented in the Figure 1.

\section{Information sources: opinion seeking}

Information seeking minimizes perceived risk in consumer purchase decision-making processes. Word-of-mouth is the most important information source for reducing risk perception and has a stronger effect on consumer decision making than mass

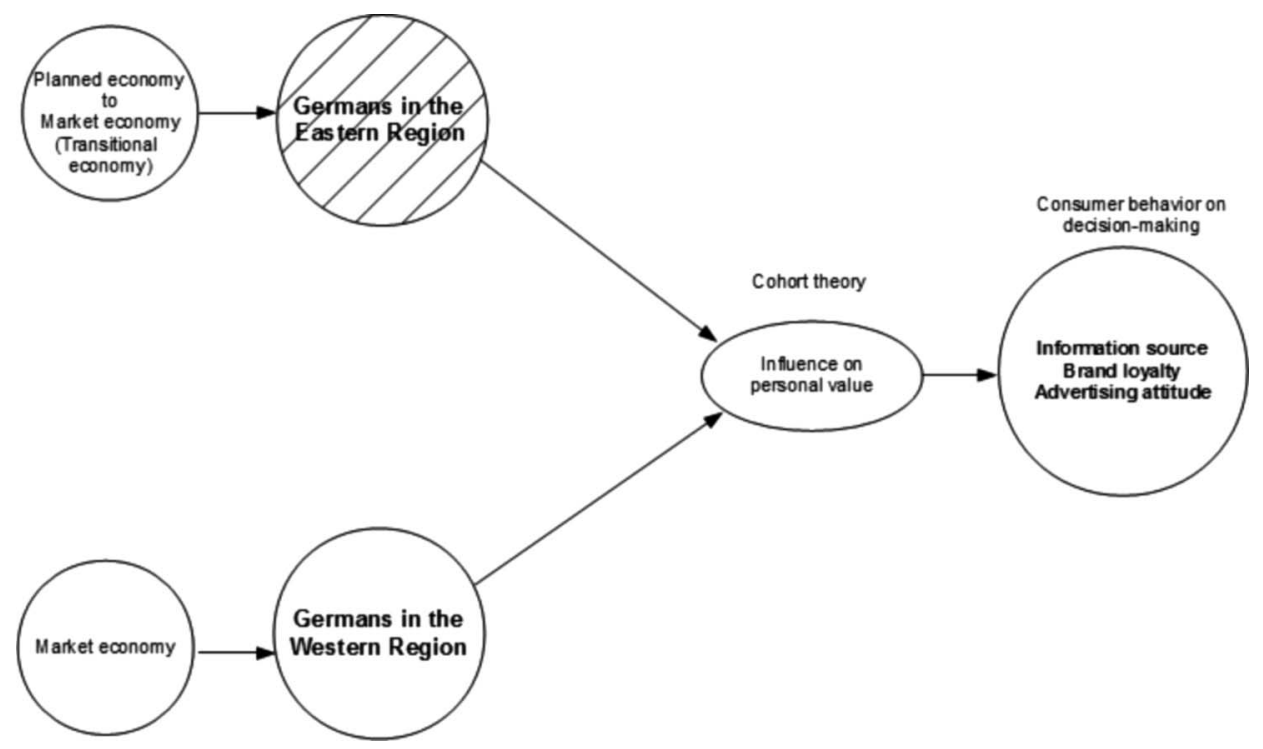

Figure 1. Proposed study model - value to consumer attitude structure model. 
media, due to opportunities for feedback and explanation (Arndt 1967; Lutz and Reilly 1973); consumers thus tend to seek product information from other people (Midgley 1983).

Johnson and Johnson (1993), as noted above, compared the information-seeking behavior of German consumers in the former East to that of consumers in the former West after the fall of the Berlin Wall. They discovered that past personal experiences, personal product examination, and others' opinions (e.g. friends and relatives) were more important information sources to consumers in the former East Germany than to consumers in the former West Germany. On the other hand, the former West Germans were more influenced by store sales personnel than former East Germans. Thus, word-of-mouth seemed to be more important to the former East German consumers.

As Inglehart (2000) demonstrated using cohort theory, economic growth (here, the transition from command economy to market economy in the former East Germany) facilitates the change of social and cultural traits. Thus, it is likely that the differences between East and West has vanished (or at least diminished) over the last 20 years, given that both regions have the same type of economy. Therefore, it is hypothesized:

Young consumers in the Eastern and Western regions of Germany are equally likely to be influenced in the purchasing decision process by:

H1-1: opinions of others.

H1-2: past experience.

H1-3: personal examination of products.

H1-4: sales people.

\section{Brand loyalty}

Brand loyalty is defined as consumer commitment to buy a certain product consistently, regardless of the situation and marketing impact (Oliver 1999). Brand loyalty minimizes perceived risk in the process of purchasing products or services (Bauer 1967; Lutz and Reilly 1973), because, to minimize perceived risk, consumers may buy a brand with which they are familiar.

Prior to 1989, German consumers had access to different products. While consumers in the former West Germany had access to Western products or international brands, few consumers in the former East Germany had access to these products, except from a few stores called Inter Stores (Ardagh 1991). However, unlike other Soviet-bloc states, some former East Germans had limited access to Western media (broadcast television and radio) and products due to their proximity to the former West Germany (Feick and Gierl 1996). Typically, Soviet-bloc markets had few competing products (Feick and Gierl 1996), the former East Germany included. Thus, in the two different economies in Germany before the reunification, people developed their own separate brand loyalties. In the case of the former East Germans, among the limited choices in the planned economy, consumers developed brand loyalty to their own domestically produced products.

However, after the reunification, many Western branded products were introduced to young German consumers in the Eastern region (Drakulic 1993; Feick, Higie, and Price 1993) while growing up in the transitional economy. A specific type of loyalty among former East German consumers (i.e. Ostalgie) has 
been discussed in the Ostalgie literature (Bach 2002; Berdahl 1999, 2010; Wicke 1998). Ostalgie describes the yearning for the past that is reflected in the buying of (or the holding of loyalty toward) brands from the former East Germany (e.g. Rotkaeppchen sparkling wine, Spreewald pickles, etc.). According to Berdahl (2010), easterners have an undermined sense of self and identity. This adds an interesting spin to the understanding of Ostalgie. The nostalgia for certain aspects of East Germany, Ostalgie, is not just a reflection of the remaining East German identity; it recalls the role of producers that easterners have lost in the economic transition. Loyalty to East German brands in an Ostalgie sense may be a way of expressing former East German identity or showing that 'not everything was bad in the East.'

However, in general, we expect that young adult consumers in the East have developed brand loyalty similar to those in the West following the reunification. Since young German consumers in the Eastern and Western regions have access to the same brands in the united Germany, we expect that they have developed similar brand loyalty while growing up in the transitional and market economies.

Therefore, hypothesis 2 proposes that:

H2: Young consumers in the Eastern and Western regions of Germany are equally likely to be brand loyal when buying electronic products twenty years after the reunification.

\section{Advertising attitude}

Marketers who design advertising strategies often view the global marketplace as homogeneous and believe that all consumers have similar needs and desires (Chan et al. 2007). Others argue that consumers may have different attitudes toward standardized advertising (Rustogi, Hensel, and Burgers 1996). However, advertising strategies that target heterogeneous marketplaces might have limited effectiveness given that different countries hold different values. In this way, advertisers need to be concerned about the way their standardized messages are perceived by consumers from different cultural and social backgrounds (Frith and Mueller 2003). Previous studies have suggested that advertising strategies should be based on local cultural values to effectively influence consumers (Ramaprasad and Hasegawa 1992). Manufacturers and retailers of products in international markets choose either standardized or adapted advertising strategies, based on their understandings of and stance toward consumer behavior. It is important to determine when standardized approaches or when adapted strategies are most appropriate given a culture's economic past and currently held dominant values.

Before the reunification, firms in the former East Germany did not engage in product advertising; rather, advertising was used for political propaganda (Feick and Gierl 1996). Within East Germany's planned economy, paid advertising by private firms was not allowed (Feick and Gierl 1996).

The literature found that consumers in the former Soviet-bloc were less skeptical toward advertising compared to Western Europe (Andrews, Durvasula, and Netemeyer 1994; Millar and Restall 1992). For the former East Germany case, empirical studies (Feick and Gierl 1996; Johnson and Johnson 1993) also found that the former East German consumers (German parents' generation now) right after the reunification were less skeptical toward advertising compared to the former West German consumers around the 1990s. 
The current study focuses on young German consumers who spent the most time in the transitional - from planned to market - economy; in other words, the former East Germans who have been exposed to a market economy in the transitional environment. Thus, we expect that attitude toward general advertising for electronic products would be similar to (but not the same as) the Germans in the Western region, who spent all their time in a market economy. According to Ford et al. (1990), consumers are sometimes more skeptical about advertising claims for high priced versus lower priced products. Thus, in the current study, we focus on general advertising attitude regarding their decision-making process about electronic products treated as high priced products. We expected that both groups would have similarly negative attitudes toward advertising in the united Germany today. In other words, it is likely the East German consumer attitudes toward advertising have migrated to the more negative attitudes found in West Germans by Johnson and Johnson (1993). This is because both young German consumers in the Eastern and Western regions of Germany have been exposed to the same media in reunified Germany. Therefore, hypothesis 3 proposes that:

H3: Young consumers in the Eastern and Western regions of Germany are equally likely to have negative attitudes toward advertising twenty years after the reunification.

\section{Research method}

\section{Sample, procedure, and instrument}

A total of 214 college students' responses to an online survey regarding electronic products (e.g. mobile phones and laptops) were collected from two universities in the Eastern (Rostock) and Western (Hamburg) regions of Germany for this intranational study. Most participants in the current study consist of subjects approximately 24 years old (East: mean $=23.51, \mathrm{SD}=2.41$ ) and 25 years old (West: mean $=25.02, \mathrm{SD}=2.76$ ). An online survey website was used to assess the purchase decision processes for electronic products. Mobile phones and laptops were chosen as the focal products for this study because of the ready availability of various brands for students. To participate in the study, laptop and mobile phone ownership were confirmed. University professors in the Hamburg and Rostock areas of Germany announced the survey web link to students in several classes offered during summer 2009 (including marketing and sports management courses) and emailed the link to them. Students voluntarily completed the survey. Participants were mainly undergraduate students, with a small portion of graduate students. To identify former East and West Germans, participants were asked, 'Where were you born (city and state)?' and 'Where did you live (most of your life) before attending university (city and state)?' The purpose of these questions was to distinguish where former East and West Germans were raised. Participants were excluded from the analysis if they (1) were Germans who answered 'born in Berlin and grew up in Berlin' because it could not be distinguished whether they were originally from the East or West areas; (2) answered 'born in' and 'grew up' in opposite areas; (3) did not own a mobile phone or laptop; or (4) were foreign students who were not Germans. There were 173 available respondents out of 214 for mobile phones: 88 East Germans and 85 West Germans. For laptops, there were 150 out of 214 available respondents: 74 East Germans and 76 West Germans. 


\section{Measurement}

A German version of the questionnaire was used. The original questionnaire was developed in English. Thus, a German graduate student fluent in both English and German translated the questionnaire from English into German. German researchers fluent in both English and German back-translated both versions of the questionnaire.

A 7 -point Likert scale $(1=$ strongly disagree to $7=$ strongly agree $)$ was used to measure information seeking, advertising attitude, and brand loyalty. Informationseeking items, adapted from Johnson and Johnson (1993), were 'I bought this mobile-phone based on past personal experience,' 'I bought this mobile-phone based on personal examination at purchase,' 'I bought this mobile-phone based on opinions of friends and relatives,' and 'I bought this mobile-phone based on the advice of the salesperson in the store.'

Brand-loyalty items, adapted from Wangenheim and Bayon (2004), included: 'I do not intend to switch my current mobile phone (or laptop) brand in the near future' and 'I would highly recommend my current mobile phone (or laptop) brand to my friends and family.' One additional item related to price and quality - 'The price I pay for the mobile phone matches the quality I receive' - was included from Johnson and Johnson (1993) because it created a better fit by factor analysis and increased scale reliability.

Three out of four items of advertising attitude were adapted from Johnson and Johnson (1993). The three adapted items were 'Advertising provides essential information for the mobile phone purchase,' 'Television is a trustworthy media,' and 'Advertising helps raise our standard of living.' One item related to price was removed.

\section{Results}

In the Eastern region of Germany, $54.5 \%$ of respondents were males and $45.5 \%$ were females $(52.5 \%)$, while in the Western region of Germany, $55.3 \%$ were males

Table 1. Characteristics of respondents.

\begin{tabular}{lr}
\hline $\mathrm{n}=173$ & Percentage \\
\hline Gender & \\
East & \\
Male & 54.5 \\
Female & 45.5 \\
West & \\
Male & 55.3 \\
Female & 44.7 \\
Age & \\
East (mean $=23.51$, SD $=2.41)$ & \\
$20-25$ & 85.2 \\
$26-30$ & 13.7 \\
Total & 98.9 \\
$31-37$ & 1.1 \\
West (mean $=25.25$, SD $=2.76)$ & \\
$20-25$ & 61.2 \\
$26-30$ & 36.4 \\
Total & 97.6 \\
$31-44$ & 2.4 \\
\hline
\end{tabular}




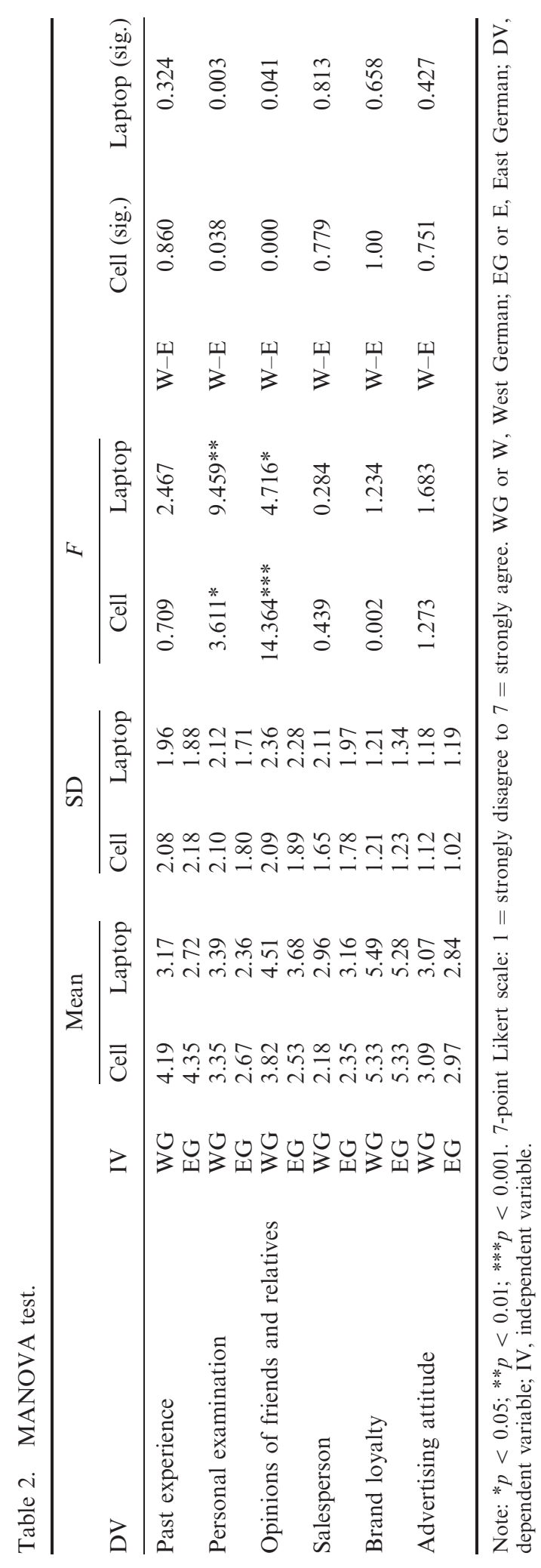




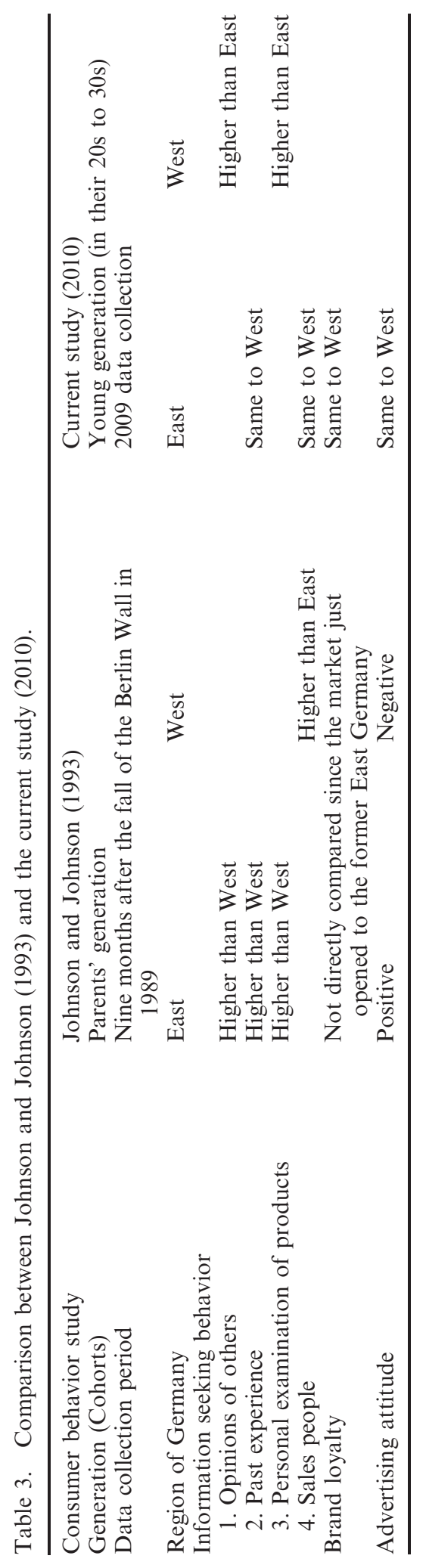


and $44.7 \%$ were females $\left(\chi_{(170)}^{2}=0.034, p>0.05\right)$. In addition, most respondents were aged between 20 and 30 years (East: $98.9 \%$ and West: 97.6\%) and the mean was 24 years old (East: $\mathrm{SD}=2.41$ ) and 25 years old (West: $\mathrm{SD}=2.76$ ). Table 1 shows the specific characteristics of young adult respondents in the Eastern and Western regions of Germany that were used in the current study.

To check internal consistency, reliabilities for brand loyalty (three items) and advertising attitude (three items) were assessed. For brand loyalty, $\alpha=0.69$ for mobile phones and $\alpha=0.79$ for laptops. For advertising attitude, $\alpha=0.68$ for mobile phones and $\alpha=0.77$ for laptops.

One-way multivariate analyses of variance (MANOVAs) for mobile phones and laptops were calculated to test for group differences of the use of information sources, brand loyalty, and advertising attitude (see Table 2). Table 3 shows the comparison between Johnson and Johnson (1993) and the current study (2010). Table 4 shows the results of hypothesis testing.

In testing H1-1 through H1-4, comparing former East and West Germans, the results indicate that the rating of opinions of friends and relatives as sources of information in the West German group was significantly greater than in the East German group. Specifically, there were differences between the former East Germans and the former West Germans for both mobile phones (2.53 vs. 3.82, $p$ $<0.001)$ and laptops (3.68 vs. 4.51, $p<0.05$ ). Thus, hypothesis H1-1 was not supported. The rating of past personal experience in the East German group was not significantly different from the West German group for mobile phones (4.35 vs. $4.19, p>0.05)$ or laptops $(2.72$ vs. $3.17, p>0.05)$. Thus, hypothesis H1-2 was supported. The rating of personal product examination in the East German group was significantly greater than in the West German group for mobile phones (2.67 vs. 3.35, $p<0.05)$ and laptops (2.36 vs. 3.39, $p<0.05)$. Thus, hypothesis H1-3 was not supported. The rating of salesperson in the East German group was not significantly different from the West German group for mobile phones (2.35 vs. 2.18, $p>0.05)$ and laptops (3.16 vs. $2.96, p>0.05)$. Thus, hypothesis H1-4 was supported.

The results for hypothesis $\mathrm{H} 2$ indicated that brand loyalty was not significantly different between the East and West Germans for mobile phones (5.33 vs. 5.33,

Table 4. Testing of hypotheses.

\begin{tabular}{|c|c|c|}
\hline Hypotheses & & Status \\
\hline & $\begin{array}{l}\text { Young consumer in the Eastern and Western regions of } \\
\text { Germany are equally likely to be influenced in the } \\
\text { purchasing decision process by: }\end{array}$ & \\
\hline Hypothesis $1-1$ & opinions of others & Not supported \\
\hline Hypothesis $1-2$ & past experience & Supported \\
\hline Hypothesis $1-3$ & personal examination of products & Not supported \\
\hline Hypothesis $1-4$ & sales people & Supported \\
\hline Hypothesis 2 & $\begin{array}{l}\text { Young consumer in the Eastern and Western regions of } \\
\text { Germany are equally likely to be brand loyal when } \\
\text { buying products. }\end{array}$ & Supported \\
\hline Hypothesis 3 & $\begin{array}{l}\text { Young consumer in the Eastern and Western regions of } \\
\text { Germany are equally likely to have negative } \\
\text { attitudes toward advertising. }\end{array}$ & Supported \\
\hline
\end{tabular}


$p>0.05)$ or for laptops (5.28 vs. 5.49, $p>0.05)$. The East and West German groups were equally brand loyal for both mobile phones and laptops. Therefore, hypothesis $\mathrm{H} 2$ was supported.

The result of the $\mathrm{H} 3$ test demonstrated that advertising attitude was not significantly different between the two German groups for either mobile phone [2.97 (E) vs. $3.09(\mathrm{~W}), p>0.05]$ or laptops [2.84 (E) vs. $3.07(\mathrm{~W}), p>0.05]$. Thus, hypothesis H3 was supported. The summary of the hypotheses is presented in Table 4.

\section{Conclusions and managerial implications}

This study expands existing Cohort Theory to consumer behavior by focusing specifically on young Germans who have experienced progressive economic and societal changes and pinpointing changes in influences on consumer decision making compared to those in 1989. In this study, we found that Inglehart's (2000) Cohort Theory applies to the case of German reunification. Overall, the differences in influences on consumer behavior between East and West Germans are smaller compared to that of Johnson and Johnson's (1993) study 20 years ago.

Our results differ from Johnson and Johnson (1993); there were no significant differences between current young former East and West Germans in their rating of the influence of past personal experiences and salesperson advice on mobile phone and laptop purchases, confirming our expectations. For past personal experience and salesperson advice, ratings from the previous former East German group were higher than those from the previous former West German group 20 years ago. In addition, in the current study, former West Germans today are more likely to be influenced by the opinions of others and personal examination of products than the former East Germans, while these two factors were more important for the East German group 20 years ago. The investigation of underlying reasons for these opposite changes would be interesting for future research.

Moreover, we found that the former East and West German groups had similar brand loyalty for both mobile phone and laptop products. These findings lend support to Cohort Theory, because 20 years ago, former East Germans had scant exposure to international brands. The reunification of East and West Germany led to the availability of many international brands. As a result of exposure to international brands since then, the cohort of former East Germans appears to be similar to their West German counterparts in brand loyalty influence. In the German market, marketers should thus focus on building brand loyalty for electronic products by providing good-quality electronic products, delivering good customer service, and developing relationship-based marketing programs. Reinforcing brand image through advertising and other marketing efforts will assist in building brand loyalty. The development of direct marketing efforts through social media also has the potential to create a bond with current customers and to bolster brand loyalty.

Both groups of German consumers expressed relatively low opinions of advertising, with mean scores below the midpoint. The current study found no significant difference in advertising attitude between the two German groups, which differs from the reports of Johnson and Johnson (1993). This finding might be explained by the exposure of both former East and West Germans to the same media 
during the transition to a market economy. Within the planned economy, paid advertising was not permitted (Feick and Gierl 1996) and the government controlled production and distribution of products. Products from private producers were not available through formal channels; advertising as a form of product information was not available.

In conclusion, since the Johnson and Johnson (1993) study, the transition from a planned economy to a market economy has resulted in some changes in influences on former East German consumer behaviors for information source, brand loyalty, and attitudes toward advertising. Differences in purchase influences between former East Germans and West Germans have decreased over the past 20 years. Study results show that the fall of the Berlin Wall in 1989 and subsequent transition to a market economy has led to changes in influence on the consumer behavior of young former East Germans. These changes can be attributed to exposure to market economy media, accessibility of international brands, and awareness of the benefits of economic growth in the reunified Germany.

\section{Limitations and future research}

While the current study is a timely and potentially interesting subject, there are some limitations that can be addressed in further studies. For future research, it would be interesting to look into the ownership duration for cell phones and laptops, because this factor may influence decision-making processes. Compared to cell phones, consumers may keep laptops longer, so consumers may use more information sources and weigh information more heavily when choosing laptops.

Some cell phone and laptop users might consider design to be an important decision criterion, which might influence respondent decision-making processes. For future research, the relationship between hedonic factors (such as design) and the influence of these factors during the decision process could provide useful information for manufacturers and retailers.

We chose our convenience student sample from the former West German area, Hamburg, and from the former East German area, Rostock. This is because college students are more likely to use laptops than noncollege students. However, it would be interesting to investigate noncollege students as well instead of the use of a convenience sample and the use of recall, rather than actual purchase behavior.

Similarities or differences could arise from the combination of natural age gap and a national event. To test whether this possible difference arises from the age gap or a cohort difference, a longitudinal method would be useful, surveying customers at regular intervals to assess changes.

\section{References}

Abramson, P., and P. Inglehart. 1995. Value change in global perspective. Ann Arbor: University of Michigan Press.

Andrews, J.C., S. Durvasula, and R.G. Netemeyer. 1994. Testing the cross national applicability of U.S. and Russian advertising belief and attitude measures. Journal of Advertising 23: 71-82.

Ardagh, J. 1991. Germany and the Germans. New York: Penguin Books. 
Arndt, J. 1967. Word of mouth advertising and information communication. In Risk-taking and information handling in consumer behavior, ed. D.F. Cox, 188-239. Boston: Harvard University Press.

Bach, J. 2002. 'The Taste Remains': Consumption, (N)ostalgia, and the production of East Germany. Public Culture 14, no. 3: 545-56.

Bauer, R.A. 1967. Consumer behavior as risk taking. In Risk-taking and information handling in consumer behavior, ed. D.F. Cox, 23-33. Boston: Harvard University Press.

Berdahl, D. 1999. '(N)Ostalgie' for the present: Memory, longing and East German things. Ethnos 62, no. 2: 192-211.

Berdahl, D. 2010. On the social life of postsocialism: Memory, consumption, Germany. Indiana: Indiana University Press.

Chan, K., L. Li, S. Diehl, and R. Terlutter. 2007. Consumers' response to offensive advertising: A cross cultural study. International Marketing Review 24, no. 5: 60628.

Drakulic, S. 1993. How we survived communism and even laughed. New York: Harper Perennial.

Egri, C.P., and D.V. Ralston. 2004. Generation cohorts and personal values: A comparison of China and the United States. Organization Science 15, no. 2: 210-20.

Fam, K., D. Waller, F. Ong, and Z. Yang. 2008. Controversial product advertising in China: Perceptions of three generational cohorts. Journal of Consumer Behaviour 7, no. 6: 461-69.

Feick, L., R.A. Higie, and L.L. Price. 1993. Consumer search and decision problems in a transitional economy: Hungary, 1989-1992. MS1 Report 93-113. Cambridge, MA: Marketing Science Institute.

Feick, L., and H. Gierl. 1996. Skepticism about advertising: A comparison of East and West German consumers. International Journal of Research in Marketing 13: 227-35.

Ford, G.T., D.B. Smith, and J.L. Swasy. 1990. Consumer skepticism of advertising claims: Testing hypotheses from economics of information. Journal of Consumer Research 16: 433-41.

Frith, K.T., and B. Mueller. 2003. Advertising and societies: Global issues. New York: Peter Lang.

Inglehart, R. 1976. The silent revolution: Changing values and political styles among western publics. Princeton, NJ: Princeton University Press.

Inglehart, R. 2000. Globalization and postmodern values. The Washington Quarterly 23, no. 1: 215-28.

Johnson, D.M., and S.D. Johnson. 1993. One Germany ... But is there a common German consumer? East-West differences for marketers to consider. The International Executive 35, no. 3: 211-28.

Lutz, R.J., and P.J. Reilly. 1973. An exploration of the effects of perceived social and performance risk on consumer information acquisition. In Advances in consumer research, ed. S. Ward and P. Wright, 393-405. Urbana, IL: Association for Consumer Research.

McKenzie, B., and B. Merrilees. 2008. Cross-cultural research in transition economies - a marketing perspective: From theory to practice. Journal of East-West Business 14, no. 2: $119-46$.

Midgley, D.F. 1983. Patterns of interpersonal information seeking for the purchase of a symbolic product. Journal of Marketing Research 20: 74-83.

Millar, C., and C. Restall. 1992. The embryonic consumer of Eastern Europe. Marketing Management I: 48-57.

Noack, P., B. Kracke, E. Wild, and M. Hofer. 2001. Subjective experiences of social change in East and West Germany: Analyses of the perceptions of adolescents and their parents. American Behavior Scientist 44: 1798-817.

Oliver, R.L. 1999. Whence consumer loyalty? Journal of Marketing 63: 33-44.

Ramaprasad, J., and K. Hasegawa. 1992. Creative strategies in American and Japanese TV commercials: A comparison. Journal of Advertising Research 32: 59-70.

Rustogi, H., P.J. Hensel, and W.P. Burgers. 1996. The link between personal values and advertising appeals: Cross-cultural barriers to standardized global advertising. Journal of EuroMarketing 5, no. 4: 57-79. 
Savitt, R. 1989. Looking back to see ahead: Writing the history of American. Journal of Retailing 65, no. 3: 326-55.

Wangenheim, F., and T. Bayon. 2004. Satisfaction, loyalty and word of mouth within the customer base of a utility provider: Differences between stayers, switchers and referral switchers. Journal of Consumer Behaviour 3, no. 3: 211-20.

Wicke, P. 1998. "Born in the GDR". Ostrock between Ostalgia and cultural self-assertion. Journal of Contemporary Central and Eastern Europe 6, no. 2: 148-55. 